\title{
Beberapa gejala disfungsi sendi temporomandibula pada anak: Penelitian pada murid SDN 2 Sengkang-Wajo Provinsi Sulawesi Selatan pada tahun 2011-2012
} Some symptoms of temporomandibular joint on child: Research at SDN 2 SengkangWajo, Province South Sulawesi in 2011-2012

\author{
Harun Achmad, Hendrastuti Handayani, Marhama F. Singgih \\ Bagian Ilmu Kedokteran Gigi Anak \\ Fakultas Kedokteran Gigi Universitas Hasanuddin \\ Makassar, Indonesia
}

\begin{abstract}
Temporomandibular joint (TMJ) has a very important role in the function of mastication, swallowing and talking. During the process of chewing, this joint sustains a large amount of stress. Some complex excessive pressure on the joints can cause structural damage to the joints or interfere with the normal function of the relationship between condyle, discus and eminence that will result in pain and dysfunction. This study aimed to determine the frequency representation of TMJ dysfunction in 6-13 years-old children. Descriptive study was conducted by survey on students of SDN 2 Sengkang-Wajo totaling 297 children, consisting of 157 males and 140 females. The sampling using a stratified random sampling, by means of sub-populations forming a relatively homogeneous state of the variables. Results showed that the frequency of TMJ dysfunction with symptoms of pain in the supporting muscles TMJ was higher (87.34\%) compared to other symptoms, followed by symptoms of mouth opening limitation (62.02\%), clicking $(43.03 \%)$, deflection $(21.51 \%)$, mouth opening deviation $(16.45 \%)$, and crepitation $(5.06 \%)$. Based on the prevalence, many students of SDN 2 Sengkang suffering from dysfunction TMJ with a variety of symptoms due to low levels of dental and oral hygiene due to lack UKGS in school.
\end{abstract}

Key words: temporomandibular joint, dysfunction of temporomandibular joint in child, SDN 2 Sengkang

\begin{abstract}
ABSTRAK
Sendi temporomandibula (STM) mempunyai peranan yang sangat penting dalam fungsi pengunyahan, penelanan dan bicara. Selama proses mengunyah, sendi ini menopang sejumlah besar tekanan. Beberapa tekanan yang berlebihan pada kompleks sendi dapat menyebabkan kerusakan pada struktur sendi atau mengganggu hubungan fungsi normal antara kondilus, diskus dan eminensia yang akan mengakibatkan rasa sakit dan disfungsi. Penelitian ini bertujuan untuk mengetahui gambaran frekuensi disfungsi STM pada anak usia 6-13 tahun. Penelitian deskriptif dengan teknik survei ini dilakukan pada siswa SDN 2 Unggulan Sengkang Kabupaten Wajo yang berjumlah 297 anak, yang terdiri dari 157 laki-laki dan 140 perempuan. Pemilihan sampel menggunakan stratified random sampling, dengan cara membentuk sub-sub populasi yang keadaan variabelnya relatif homogen. Hasil menunjukan bahwa frekuensi disfungsi STM dengan gejala nyeri pada otot-otot pendukung STM lebih tinggi $(87,34 \%)$ dibandingkan gejala yang lain, diikuti dengan gejala keterbatasan bukaan mulut (62,02\%), kliking (43,03\%), defleksi $(21,51 \%)$, deviasi bukaan mulut (16,45\%), dan krepitasi (5,06\%). Berdasarkan prevalensi tersebut, disimpulkan banyaknya siswa SDN 2 Sengkang yang mengalami disfungsi STM dengan berbagai gejala akibat rendahnya tingkat kebersihan gigi dan mulut akibat ketiadaan UKGS di sekolah.
\end{abstract}

Kata kunci: sendi temporomandibula, disfungsi sendi temporomandibula anak, SDN 2 Sengkang

Koresponden: Harun Achmad, E-mail:harunachmad@yahoo.com

\section{PENDAHULUAN}

Sendi temporomandibula (STM) merupakan sendi yang sangat kompleks, karena membuka dan menutup,bergeser ke anterior dan posterior,dan dari sisi yang satu ke sisi yang lainnya seperti engsel. Sendi ini memiliki peran yang sangat penting dalam fungsi pengunyahan, penelanan dan bicara. ${ }^{1}$ Selama proses mengunyah, sendi ini menopang sejumlah besar tekanan. Tekanan yang berlebih pada kompleks sendi dapat menyebabkan kerusakan struktur sendi atau mengganggu hubungan fungsi normal antara kondilus, diskus dan eminensia yang akan mengakibatkan rasa nyeri, disfungsi atau duanya., ${ }^{2,3}$
Disfungsi STM dapat terjadi pada orang dewasa atau anak.Kebiasaan buruk pada anak seperti tongue thrust, menggigit-gigit kuku atau pensil, mengisap jari dan mengunyah pada satu sisi,dan kondisi oral hygiene yang buruk yang menyebabkan kehilangan dini gigi posterior merupakan faktor yang memicu terjadinya disfungsi STM. Pada anak, disfungsi ini jarang menimbulkan rasa nyeri,tetapi bila dibiarkan dikhawatirkan terjadi disfungsi yang lebih lanjut, sehingga menimbulkan keluhan seperti nyeri saat membuka mulut, nyeri kepala,atau nyeri telinga. ${ }^{4,5}$

Disfungsi STM bisa mengenai sendi dan otototot di sekitarnya. Gejala yang menyertainya dapat 
berupa bunyi sendi yang disebut sebagai kliking atau krepitasi,gerak mandibula yang asimetris atau terbatas, dan kadang-kadang disertai nyeri pada rahang, telinga, kepala dan wajah. ${ }^{6}$

Gejala kliking merupakan gejala yang paling sering menyertai disfungsi STM. ${ }^{7}$ Hasil penelitian yang dilakukan Ogura pada remaja berusia 10-18 tahun, menunjukkan $10,1 \%$ menderita disfungsi STM,meliputi kliking sebesar $87,5 \%$ atau $86 \%$ dari seluruh sampel. ${ }^{8}$ Penelitian Emmilya pada anak sekolah dasar di desa tertinggal di Kecamatan Cimalaka Kabupaten Sumedang menyatakan bahwa kesadaran untuk mencegah dan perawatan disfungsi STM masih minim.Hal ini dapat telihat dari jumlah penderita disfungsi STM dengan gejala kliking masih cukup besar, yaitu sebesar 33,33\%. ${ }^{9}$ Gejala lain yang seringkali dikeluhkan oleh penderita disfungsi STM adalah nyeri otot pada daerah TMJ, yaitu otot-otot pengunyahan. Adanya keterkaitan antara otot-otot pengunyahan dengan otot di sekitar kepala, leher dan punggung mengakibatkan penderita sering mengeluh adanya rasa nyeri di sekitar kepala, leher dan punggung. ${ }^{7,8}$

Penelitian yang telah dilakukan sebelumnya pada anak,kebanyakan terbatas membahas disfungsi STM dengan gejala kliking.Gejala-gejala disfungsi STM lainnya seperti krepitasi,keterbatasan bukaan mulut dan nyeri otot di sekitar STM perlu dibahas lebih lanjut karena pencegahan secara dini dan perawatan yang dilakukan pada anak mempunyai peran penting terhadap terjadinya disfungsi STM.

Berdasarkan latar belakang di atas,maka perlu diketahui gambaran frekuensi disfungsi STM pada anak SDN 2 Sengkang.Data penelitian ini diharap dapat dijadikan acuan dasar dalam menangani perawatan gigi mulut di komunitas tertentu yang diwakili oleh sampel yang diambil di daerah ini.

\section{BAHAN DAN METODE}

Penelitian deskriptif dengan teknik survei ini mengambil populasi anak yang bersekolah di SDN 2 Unggulan Sengkang-Wajo yang berjumlah 297 anak, terdiri atas 157 laki-laki dan 140 perempuan. Digunakan teknik stratified random sampling untuk membentuk sub-sub populasi yang variabelnya relatif homogen. Variabel yang diteliti adalah jenis kelamin, usia,dan gejala-gejala disfungsi STM yang meliputi kliking, krepitasi, deviasi bukaan mulut, defleksi bukaan mulut, keterbatasan bukaan mulut, dan nyeri otot pendukung STM.

\section{Definisi operasional}

Disfungsi STM dengan gejala kliking adalah adanya bunyi tunggal klik pada saat membuka atau menutup mulut, sedangkan gejala krepitasi adalah adanya bunyi jamak krek, yang mengganggu pada saat membuka atau menutup mulut. Pemeriksaan keduanya dilakukan dengan palpasi di depan telinga luar,dan auskultasi dengan menggunakan stetoskop.

Disfungsi STM dengan gejala keterbatasan pembukaan mulut adalah adanya perbedaan antara jarak interinsisal, yaitu jarak yamg diukur dari incisal edge pada pembukaan mulut lebar secara perlahan pada saat rasa nyeri pertama muncul, dengan jarak interinsisal pembukaan lebar mulut maksimal. Pengukuran jarak interinsisal dilakukan dengan menggunakan penggaris.

Disfungsi STM dengan gejala deviasi dan defleksi bukaan mulut adalah kelainan yang ditandai dengan pergeseran midline arah gerak mandibula pada saat pembukaan mulut.Deviasi ditandai dengan pergeseran midline arah gerak mandibula pada saat pembukaan awal. Namun pada akhir bukaan mulut, gerak mandibula kembali ke arah midline.Sedangkan defleksi ditandai dengan pergeseran midline gerak mandibula dari awal sampai dengan akhir bukaan mulut.

Disfungsi STM dengan gejala nyeri otot adalah adanya rasa nyeri dan ketidaknyamanan pada daerah otot yang diperiksa (otot temporalis, maseter, pterigoideus lateralis,pterigoideusmedialis, trapezius, sternokleidomastoideus, servikalis posterior) saat dilakukan palpasi dan manipulasi fungsional.

Batas umur anak dihitung berdasarkan ulang tahun terakhirpada saat penelitian dilakukan;apabila umur anak lebih dari 6 bulan dari tanggal kelahiran maka umur anak dibulatkan ke atas.

\section{Jalannya penelitian}

Sampel disilakan duduk pada kursi yang telah disediakan, lalu dicatat identitasnya. Pemeriksaan klinis disfungsi STM dengan gejala kliking dan krepitasi dilakukan dengan cara meletakkan jari telunjuk pada liang telinga sambil ditekan, diraba kelancaran gerakan kondilus selama membuka dan menutup mulut.Peluncuran yang tidak rata dan bunyi klik disebut adanya kliking,sementara peluncuran yang tidak rata dan bunyi krek yang mengganggu menunjang adanya krepitasi.Pemeriksaan dilakukan dengan menggunakan stetoskop pada bagian lateral setiap sendi.

Pemeriksaan klinis disfungsi STM dengan gejala keterbatasan bukaan mulut dilakukan dengan cara menginstruksikan pasien membuka mulutnya secara perlahan-lahan sampai terasa rasa nyeri yang pertama,kemudian diukur jarak antara interinsisal dengan penggaris. Selanjutnya, sampel membuka mulutnya secara maksimal, kemudian diukur jarak 
Tabel 1 Persentase penderita disfungsi STM dengan gejala kliking berdasarkan sisi STM yang terkena dan waktu terjadinya kliking

\begin{tabular}{|c|c|c|c|c|c|c|}
\hline \multicolumn{7}{|c|}{ Penderita disfungsi STM dengan gejala kliking } \\
\hline & \multicolumn{2}{|c|}{ Kliking Unilateral } & \multicolumn{2}{|c|}{ Kliking Bilateral } & \multicolumn{2}{|c|}{ Total } \\
\hline & Jumlah (n) & $\%$ & Jumlah (n) & $\%$ & Jumlah (n) & $\%$ \\
\hline Pembukaan & 3 & 3,79 & 3 & 3,79 & 6 & 7,58 \\
\hline Resiprokal & 7 & 8,86 & 21 & 26,58 & 28 & 35,44 \\
\hline Total & 10 & 12,65 & 24 & 30,37 & 34 & 43,02 \\
\hline
\end{tabular}

maksimal, kemudian diukur jarak interinsisalnya. Selisih kedua pengukuran jarak interinsisal tersebut menunjuk adanya keterbatasan bukaan mulut. ${ }^{1.9}$

Pemeriksaan klinis dilakukan dengan teknik palpasi, yaitu dengan meletakkan jari telunjuk, jari tengah, dan jari manis pada daerah otot yang akan diperiksa. Palpasi dilakukan sesuai teknik yang diperkenalkan oleh Okeson, yaitu dengan menekan jari-jari tersebut secara lembut dan tegas sekaligus membentuk gerakan sirkular. Adanya rasa nyeri dan ketidaknyamanan dari pasien selama tindakan ini menunjuk adanya nyeri otot pada daerah sekitar STM. Setiap palpasi berbeda teknik dan letaknya, tergantung letak anatomi otot yang akan diperiksa.

Data yang diolah untuk menggambarkan frekuensi disfungsi STM dengan gejala kliking, krepitasi, keterbatasan pembukaan mulut dan nyeri otot di sekitar STM. Hasil pengolahannya disajikan dalam bentuk tabel.

\section{HASIL}

Dari Tabel 1, diketahui bahwa jumlah siswa SDN2 Unggulan Sengkang yan menderita disfungsi STM dengan gejala kliking unilateral adalah 10 siswa $(12,65 \%)$, sedangkan jumlah siswa yang mengalami disfungsi STM dengan gejala kliking bilateral sebanyak 24 anak $(30,38 \%)$. Hal tersebut menunjukkan bahwa frekuensi kliking bilateral lebih banyak dibandingkan dengan kliking unilateral.

Berdasarkan saat terjadinya, anak yang mengalami kliking pembukaan unilateral adalah 3 anak $(3,79 \%)$ dan kliking resiprokal unilateral 7 siswa $(8,86 \%)$, sedangkan jumlah siswa yang mengalami kliking pembukaan bilateral sebanyak 3 siswa $(3,79 \%)$ dan kliking resiprokal bilateral adalah 21 (26,58\%). Berdasar saat terjadinya kliking pembukaan dan resiprokal unilateral adalah sama, sedang frekuensi disfungsi STM dengan gejala kliking resiprokal bilateral jauh lebih tinggi dibanding dengan kliking pembukaan bilateral. Ini berarti ketidakseimbangan otot pada siswa SDN 2 Sengkang cukup tinggi, karena terjadinya kliking pembukaan dan resiprokal terkait dengan tingkat keparahan disfungsi STM.

Tabel 2 menunjukkan jumlah siswa SDN 2 Unggulan Sengkang-Wajo yang mengalami gejala krepitasi relatif kecil.
Tabel 2 Persentase penderita disfungsi STM dengan gejala krepitasi pada anak SDN 2 Sengkang-Wajo Penderita disfungsi STM dengan gejala krepitasi Jumlah Anak Presentase
(n)
$(\%)$

$4 \quad 5,06$

Hasil penelitian menyatakan bahwa diketahui jumlahanak yang mengalami disfungsi STM dengan gejala deviasi pada pembukaan mulut adalah 13 anak $(16,45 \%)$ dan gejala defleksi pada pembukaan mulutadalah 17 anak $(21,51 \%)$, sedangkan penderita disfungsi STM dengan gejala keterbatasan bukaan mulut sebesar 49 anak (42,02\%) (Tabel 3).

Tabel 3 Persentase penderita disfungsi STM dengan gejala deviasi, defleksi dan keterbatasan bukaan mulut pada siswa SDN 2 Unggulan Sengkang-Wajo

\begin{tabular}{ccc}
\hline Gejala penderita & $\begin{array}{c}\text { Jumlah anak } \\
\text { disfungsi STM }\end{array}$ & $\begin{array}{c}\text { Presentase } \\
(\mathrm{n})\end{array}$ \\
\hline Deviasi bukaan mulut & 13 & 16,45 \\
Defleksi bukaan mulut & 17 & 21,51 \\
Terbatasnya bukaanmulut & 49 & 62,02 \\
\hline
\end{tabular}

Pada tabel 4 dapat diketahui bahwa frekuensi disfungsi STM dengan gejala nyeri otot pendukung STM sangat tinggi, 69 anak (87,34\%).

Tabel 4 Frekuensi gejala nyeri pada otot pendukung STM pada siswa SDN 2 Unggulan Sengkang-Wajo penderita disfungsi STM

\begin{tabular}{ccc}
\hline $\begin{array}{c}\text { Penderita disfungsi TMJ } \\
\text { dengan gejala nyeri otot }\end{array}$ & $\begin{array}{c}\text { Jumlah anak } \\
(\mathrm{n})\end{array}$ & $\begin{array}{c}\text { Persentase } \\
(\%)\end{array}$ \\
\hline Otot Temporal & 8 & 10,12 \\
Otot Masseter & 15 & 31,80 \\
Otot Pterigoid & 17 & 21,52 \\
Otot Sternokleidomastoid & 14 & 17,72 \\
Otot Servikal Posterior & 15 & 31,80 \\
\hline Jumlah & 69 & 87,34 \\
\hline
\end{tabular}

\section{PEMBAHASAN}

Penderita disfungsi STM dengan gejala kliking pada Anak SDN 2 Unggulan Sengkang didapatkan frekuensinya $43,02 \%$ (tabel 1), menunjukkan nilai yang hampir sama dibandingkan dengan anak-anak sekolah dasar di Kotamadya Makassar pada usia yang sama. ${ }^{11}$ Hal ini bisa disebabkan oleh karena adanya kemiripan dalam pola kebiasaan,pola makan, 
dan sikap tubuh (body posture). Pada Anak SDN 2 Unggulan Sengkang yang sudah berada di wilayah kotakabupaten,pola makannya telah memenuhi akan asupan gizi yang sehat diikuti dengan pola hidup sehat yang baik. Tingkat kebersihan dan kesehatan gigi dan mulut di wilayah kota kabupaten relatif mirip dibandingkan dengan wilayah perkotaan. Hal inidiakibatkan oleharus informasi tentang kesehatan gigidan mulut dan tingkat sosio-ekonomi di wilayah ibukota kabupaten yang sudah semakin baik dan maju. Di wilayah ibukota kabupaten kesehatan gigi dan mulut telah mulai menjadi prioritas penting dalam menjaga kesehatan tubuh.

Dari Tabel 1, tampak bahwa frekuensi kliking bilateral lebih banyak dibandingkan dengan kliking unilateral. Kondisi demikian dihubungkan dengan prevalensi karies yang tinggi, yang menyebabkan kehilangan dini gigi posterior pada kedua rahang, sehingga menyebabkan maloklusi.

Secara umum, terjadinya kliking unilateral dan bilateral berhubungan dengan ketidakseimbangan otot, akibat karies pada salah satu sisi, restorasi yang kurang sempurna, dan kebiasaan mengunyah pada salah satu sisi. Pada siswa SDN 2 Unggulan Sengkang-Wajo, oral hygiene-nya masuk kategori sedang, akibat masih minimnya pengetahuan anak terhadap kebersihan gigi dan mulut, dan mungkin belum intensifnya kegiatan penyuluhan kesehatan gigi dan mulut di SDN tersebut.

Krepitasi merupakan salah satu gejala dari disfungsi STM yang seringkali mengganggu pada saat pergerakan sendi. Gejala tersebut dapat disertai rasa nyeri pada daerah STM. Krepitasi biasanya disebabkan oleh proses perubahan degeneratif dari permukaan struktur TMJ. ${ }^{1,12}$ Oleh karena itu pada anak-anak, gejala disfungsi STM ini relatif jarang ditemukan (tabel 2).
Deviasi dan defleksi merupakan gejala yang seringkali ditemukan pada penderita disfungsi STM, dengan tanda klinis berupa penyimpangan midline gerakan mandibula pada saat pembukaan mulut. Sedangkan keterbatasan bukaan mulut merupakan tanda klinis dengan gejala pasien sulit membuka mulutnya secara maksimal.Hal ini dapat terjadi pada disfungsi STM dengan disc displacement without reduction,yang menyebabkan terjadinya pergerakan mandibula terbatas dan terjadinya deviasi maupun defleksi pergerakan mandibula. ${ }^{2-4} \mathrm{Hal}$ ini seringkali juga disebabkan oleh hiperaktivitas otot pendukung STM yang berlebih, yang sering ditemukan pada anak dengan karies gigi dan yang memiliki oral habit yang buruk. ${ }^{2.5}$

Tingginya prevalensi karies merupakan salah satu penyebab terjadinya disfungsi STM. Pada keadaan ini, otot pengunyahan, otot pembuka dan penutup mulut bekerja di atas normal,sehingga mengganggu struktur STM. ${ }^{5,8}$ Pada siswa SDN 2 Unggulan Sengkang-Wajo, didapatkan prevalensi karies anak tersebut masih sedang.Hal ini dapat diakibatkan dari minimnya perhatian orang tua terhadap penjagaan kebersihan mulut dari anaknya, atau akibat arus informasi yang masih kurang pada masyarakat Kabupaten Wajo. Lain halnya dengan anak yang tinggal di perkotaan. Anak-anak tersebut memiliki kecenderungan meningkatnya disfungsi TMJ akibat adanya restorasi yang kurang sempurna, kehilangan banyak gigi posterior, dan kebiasaan buruk, seperti mengisap jari. ${ }^{11}$

Penderita disfungsiSTM kerap mengeluh adanya rasa nyeri dan tidak nyaman pada otot pendukung STM. Hal ini diakibatkan oleh ketidakseimbangan penggunaan otot, diantaranya terjadi akibat prevalensi karies yang tinggi,kebiasaan mengunyah pada salah satu sisi, ataupun penyimpangan sikap tubuh. ${ }^{3.7}$

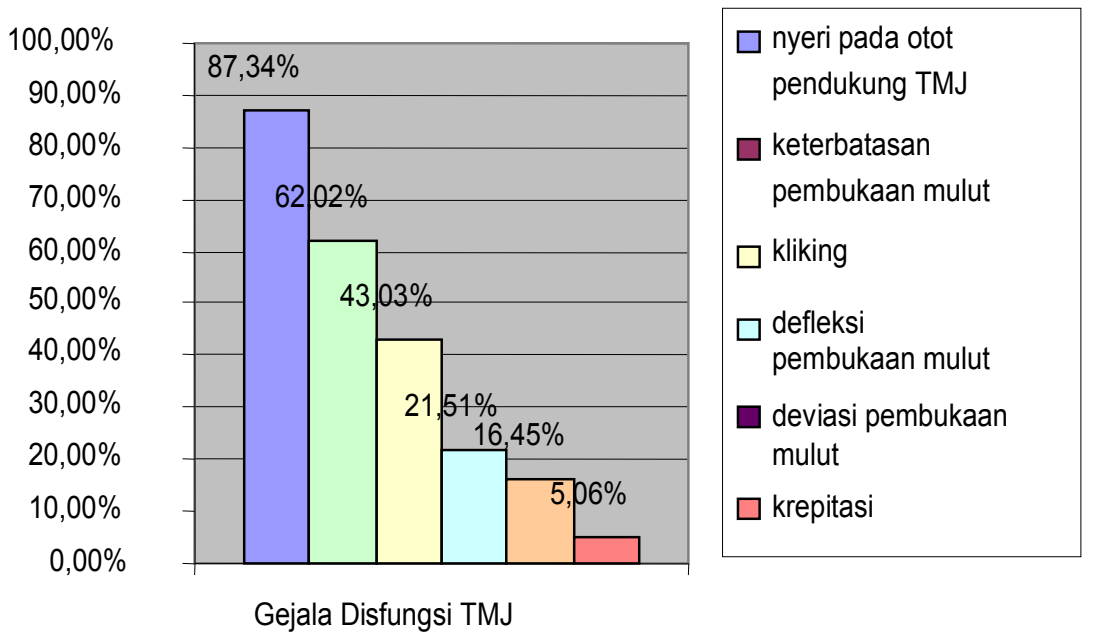

Gambar 1 Grafik batang prevalensi disfungsi STM pada siswa SDN 2 Sengkang 
Tingginya frekuensi nyeri otot sebagai gejala disfungsi STM, dapat diakibatkan oleh karena pada anak seringkali terjadi kebiasaan penyimpangan sikap tubuh dalam kehidupan sehari-hari. Contoh sikap tubuh yang keliru, diantaranya adalah sikap duduk yang salah saat melakukan kegiatan belajar, kebiasaan menjinjing tas pada satu sisi, ataupun pada anak perempuan belasan tahun yang sering berjalan bungkuk untuk menyembunyikan payudara yang baru berkembang. Penyimpangan sikap tubuh bila dibiarkan dapat menyebabkan gangguan pada keseimbangan otot leher,otot pembuka dan penutup mulut, selanjutnya akan mempengaruhi STM. ${ }^{5,6}$

Berdasarkan data, diperoleh frekuensi disfungsi TMJ dengan gejala nyeri pada otot-otot pendukung TMJ lebihtinggi $(87,34 \%)$ dibandingkan gejala yang lainnya,diikuti dengan gejala keterbatasan bukaan mulut (62,02\%),kliking (43,02\%), defleksi (21,51\%), deviasi pembukaan mulut $(16,45 \%)$, dan krepitasi $(5,06 \%)$ (Grafik 1). Hal ini dapat diakibatkan oleh ketidakseimbangan penggunaan otot, diantaranya dapat terjadi akibat prevalensi karies yang tinggi, kebiasaan mengunyah pada salah satu sisi, ataupun penyimpangan sikap tubuh. ${ }^{4,8}$

Beberapa hasil penelitian menunjukkan bahwa masyarakat dengan tingkat pendidikan dan ekonomi yang rendah cenderung memiliki prevalensi karies yang tinggi, yang kemudian akan mempengaruhi STM. ${ }^{4,8}$ Hal tersebut terjadi pada anak SDN 2 Unggulan Sengkang-Wajo yang memiliki perhatian yang kurang terhadap penjagaan kesehatan gigi dan mulut, akibatnya prevalensikaries makin meningkat. Karena tidak dilakukan perawatan/restorasi, tingkat keseimbangan otot semakin meningkat dan akan mempengaruhi kondilus, sehingga menyebabkan terjadinya pergerakan mandibula yang terbatas dan asimetris, kliking maupun krepitasi. ${ }^{1,4,9}$ Untuk itu, pencegahan dan perawatan dini penting dilakukan untuk mencegah disfungsi STM yang lebih lanjut.

Berdasarkan pembahasan hasil penelitian ini, disimpulkan bahwa siswa Sekolah Dasar Negeri 2 Sengkang-Wajo yang mengalami disfungsi STM dengan gejala kliking, deviasi dan defleksi bukaan mulut, keterbatasan pembukaan mulut, dan nyeri pada otot pendukung STM cukup tinggi.Sedangkan gejala krepitasi relatif rendah. Hal ini diakibatkan rendahnya tingkat kebersihan gigi dan mulut anak, yang disebabkan oleh minimnya pengetahuan anak dan orang tua terhadap penjagaan kebersihan dan kesehatan gigi dan mulut, mengingat masih belum terselenggaranya penyuluhan kesehatan gigi dan mulut di sekolah tersebut.

\section{DAFTAR PUSTAKA}

1. Okeson JP. Management of temporomandibular disorders. $2^{\text {nd }}$ Ed. St. Louis: CV. Mosby Co.; 1989.

2. Pertes RA, Gross SG. Clinical management of temporomandibular disorders and orofacial pain. Illinois: Quintessence Publishing, Co. Inc.; 1995.

3. Prater ME, Bailey BJ. Temporomandibular joint disorders. Texas: The University of Texas Medical Branch; 1998.

4. Hollenstein J. Temporomandibular joint (TMJ) syndrome: Temporomandibular joint disorder; temporomandibular joint dysfunction; myofacial pain dysfunction syndrome. 2006. http://www.tmj.org (diakses 2 Januari 2006). 2006

5. Bernal MA, Tsamtsouris. Signs and symptom of temporomandibular joint sound. J Pedodont 1996; 10 (2): 10-3.

6. Carlsson GH, Magnusson T. Management of temporomandibular disease in general dental practice. Stockholm: Quintessence Pub. Inc.; 1999.

7. Chaudhary A. Temporomandibular Joint Syndrome. 2004. Available from: http://www.eMedicine.com. Accessed on February 27, 2006.

8. Cooper BC. Temporomandibular disorders TMJ-TMD and facial pain. 2005. Available from: http://www.tmj.com. Accessed on January 2, 2006.

9. Grace E. Frekuensi disfungsi sendi temporomandibula dengan gejala kliking pada anak sekolah dasar desa tertinggal di Kecamatan Cimalaka Kabupaten Sumedang [Skripsi]. Bandung: Universitas Padjadjaran; 2001.

10. Notoatmodjo. Metodologi penelitian bidang kesehatan, keperawatan, dan kebidanan.Yogyakarta: Fitramaya; 2002.

11. Patimah TS. Frekuensi disfungsi temporomandibular joint dengan gejala kliking pada anak sekolah dasar negeri di Kotamadya Bandung [Skripsi]. Bandung: Universitas Padjadjaran; 1998.

12. Suryanto R. Perbedaan letak kondilus sendi temporomandibular pada kasus disfungsi dengan gejala dan tanpa gejala keletuk sendi dilihat secara radiografik. Majalah Ilmu Kedokteran Gigi Usakti 1993; edisi khusus Forum Ilmiah IV, Vol.2. 